\title{
Economic growth and structural change in a multi-sector and multilateral approach to balance-of-payments constrained growth
}

\author{
Crescimento econômico e mudança estrutural \\ numa abordagem multissetorial e multilateral de \\ crescimento restrito pelo balanço de pagamentos
}

RICARDO AZEVEDO ARAUJO, MATHEUS SILVA DE PAIVA JULIO FERNANDO COSTA SANTOS GUILHERME JONAS COSTA DA SILVA*

\begin{abstract}
RESUMO: Este artigo tem por objetivo desenvolver um modelo multissetorial e multilateral de crescimento restrito pelo balanço de pagamentos. Para tanto, utiliza-se como base os modelos propostos por Araujo e Lima (2007) e Nell (2003). Além disso, o artigo apresenta algumas simulações computacionais a fim de ilustrar como a mudança estrutural no sentido de Pasinetti-Kaldor (1993) afeta o crescimento econômico de longo prazo. Essa contribuição torna-se relevante por tornar viável a identificação de quais os setores e parceiros comerciais que mais contribuem para o crescimento de longo prazo da economia doméstica, bem como propor políticas econômicas e industriais que melhorem as relações comerciais e a competitividade da economia.

PALAVRAS-CHAVE: Mudança estrutural; crescimento restrito pelo balanço de pagamentos; parceiros comerciais.
\end{abstract}

ABSTRACT: This study aims to develop a multi-sector and multilateral model of balance-ofpayments constrained growth. As a starting point, we adopted the models proposed by Araujo and Lima (2007) and Nell (2003). The paper also presents computer simulations to test how structural changes in the Pasinetti-Kaldor sense affect long-term economic growth. This approach is relevant insofar as it enables the identification of sectors and trading part-

\footnotetext{
* Respectively, Associate Professor of Economics at the Universidade de Brasilia (UnB). E-mail: rsaaraujo@unb.br; Assistant Professor of Economics at Universidade Católica de Brasilia (UCB). E-mail: matheus.paiva@gmail.com; Ph.D. Student in Economics at the Universidade Federal de Uberlândia (UFU). E-mail: arnldin@gmail.com; Associate Professor at the Universidade Federal de Uberlândia (UFU). E-mail: guilhermejonas@ie.ufu.br Submitted: 31/July/2015; approved: 26/ September/2016.
} 
ners that contribute the most to long-term growth, as well as proposing economic and industrial policies that improve trade relations and economic competitiveness.

KEYWORDS: Structural change; balance-of-payments constrained growth; trading partners. JEL Classification: E12; F43; O41.

\section{INTRODUCTION}

This article aims to develop a multi-sector and multilateral model of balanceof-payments constrained growth. The literature, initially based on Thirlwall's model (1979), has advanced in two main directions. In the first phase, Thirlwall's law was extended to consider more inclusive versions of balance-of-payments, such as capital flows [Thirlwall and Hussain (1982)], external debt [McCombie and Thirlwall (1997) and Moreno-Brid (1998-99)], interest payments on debt [Elliot and Rhodd (1999)], etc. More recently, a second wave of extensions has focused on more disaggregated versions of this empirical regularity. Araujo and Lima (2007), for instance, follow a structural dynamic approach [see, e.g., Pasinetti (1993) and Araujo and Teixeira (2004)] and have shown that, in order to overcome external constraint, a country should pursue a strategy related to changes in the production structure. According to this view, export and import elasticity may be considered as average means of sector export and import elasticity, in which the weight of each sector's elasticity is each sector's share of trade. With such derivations, the authors demonstrated that, even when sector elasticity and world income growth are constant, a country can grow more quickly, either by increasing the export share of sectors with high-income elasticity of exports, or by decreasing the import share of sectors with high income elasticity of imports.

This paper highlights the fact that higher levels of disaggregation provide a better understanding of the factors that can boost growth, particularly in underdeveloped and emerging countries. This extension considers the relationship between production structure and balance-of-payments and also, alongside the original model [Thirlwall (1979)], assumes the existence of just one commercial partner, generically labelled as "the rest of the world", neglecting to acknowledge the existence of other commercial partners and their effects on domestic growth. This assumption, although useful in the initial phases of investigation, is not compatible with the reality of multiple commercial partners in a globalized world. This points to the need for the country under consideration to pursue particular trade strategies with its various commercial partners.

To fill this gap, Nell (2003), advanced an extension of the baseline model [Thirlwall (1979)] which takes more than two commercial partners into account. This contribution is relevant, since it focuses on the identification of trading partners that contribute the most to long-term growth and enables us to consider economic and industrial policies that improve trade relations with such partners. The author derived a multilateral version of Thirlwall's law, in which the weight of each 
commercial partner is considered in determining the balance-of-payments constrained growth rate. According to this formulation, a country may experience higher growth rates when most of its exports are attributed to commercial partners that demand goods with higher income elasticity of exports. In this vein, this extension emphasizes the importance of a disaggregated approach to balance-of-payments constrained growth, in terms of either sectors or commercial partners.

Given this context, this article puts forward a derivation of an extended version of Thirlwall's law in terms of disaggregation in both sectors and commercial partners. This development is important, since it enables the simultaneous identification of sectors and commercial partners that contribute the most to long-term economic growth, allowing us to focus on policies that improve trade relations and economic competitiveness. This analysis reinforces the notion that, beyond income elasticity of exports and imports, the sector composition of countries involved in trade is also relevant to economic performance. The results show that from a balance-of-payments constrained growth perspective, economies with structures locked into the production and export of goods with low income elasticity and the import of goods with high income elasticity may face barriers to higher growth rates. This result is confirmed from both the theoretical and computational viewpoint, since the study also contains numeral simulations to illustrate these results. By considering a fictitious economy with features similar to the Brazilian economy in terms of three of its main commercial partners, namely the USA, China and Argentina, numerical simulations demonstrated that the Brazilian economy's current trade pattern, favouring the export of low income elasticity goods, is harmful to growth and reduces the chance of catch-up with developed countries. In an alternative scenario, where the Brazilian economy implements structural changes and moves towards the production and export of goods with more value added, growth performance is seen to be consistent with the existence of a virtuous cycle of growth, as highlighted in the Kaldorian literature. These structural changes are not the byproduct of a market mechanism, rather, they require state policies to succeed.

This article is divided into five sections. In the next section, we review Thirlwall's Law and its multilateral extension. In the third, we present the Multisector Thirlwall's Law (MSTL), while in the fourth, we derive the Multisector Thirlwall's Law with an arbitrary number of commercial partners (MMSTL). In the fifth section, we present the computational simulations for the trajectory of per capita GDP and the economic growth rate in a fictitious economy similar to Brazil. In the sixth and final section, we present certain considerations.

\section{THIRLWALL'S LAW AND THE MULTILATERAL EXTENSION}

Balance-of-payment constrained growth models demonstrate how external constraint may affect economic growth. According to this approach, a country cannot grow faster than a rate consistent with the balance of payments equilibrium over the long term. This empirical regularity was first observed by Thirlwall (1979), who 
demonstrated that the most important constraint to long-term economic growth arises from the necessary dynamic equilibrium in the balance of payments, which is provided by the export growth rate multiplied by the inverse of the income elasticity of imports. The empirical validity of this theory has been tested for several countries and, in most cases, is able to predict product growth rates [Palley (2002)]. Moreno-Brid (1998) and McCombie and Thirlwall (1994) verified its validity for underdeveloped countries and Dutt (2002) demonstrated that Thirlwall's approach may be applied to explain uneven development in north-south models. Thirlwall's Law is derived from the demand function for exports, $X$, and the demand function for imports, $M$, and the balance-of-payment equilibrium condition:

$$
\begin{aligned}
& X=\left\{\frac{P_{d}}{E P_{f}}\right\}^{\tau} Z^{\zeta} \\
& M=\left(\frac{E P_{f}}{P_{d}}\right)^{\psi} Y^{\varphi}
\end{aligned}
$$

where $P_{d}$ and $P_{f}$ are the relative domestic and foreign prices, respectively. The nominal exchange rate between these countries is given by $E$. Price elasticity are given by $\psi$ and $\tau$. The domestic and world incomes are represented by $Y$ and $Z$, respectively, while the income elasticity for exports and imports are given by $\zeta$ and $\varphi$, respectively. To maintain balanced trade, it is necessary that:

$$
P_{d} X=E P_{f} M
$$

Taking logarithms and differentiating expressions (1), (2) and (3) we obtain:

$$
\begin{aligned}
& \hat{x}=\tau\left(\hat{p}_{d}-\hat{p}_{f}-\hat{e}\right)+\zeta \hat{z} \\
& \hat{m}=\psi\left(\hat{p}_{f}+\hat{e}-\hat{p}_{d}\right)+\varphi \hat{y} \\
& \hat{p}_{d}+\hat{x}=\hat{p}_{f}+\hat{e}+\hat{m}
\end{aligned}
$$

where the circumflex above the variable indicates the rate of growth. Replacing (4) and (5) with equation (6), following algebraic manipulation, we obtain:

$$
(1+\tau+\psi)\left(\hat{p}_{d}-\hat{p}_{f}-\hat{e}\right)+\zeta \hat{z}=\varphi \hat{y}
$$

To obtain Thirlwall's Law, we can assume purchasing power parity, PPP, hereafter a hypothesis that asserts that changes in the nominal exchange rate balance domestic and external inflation, that is, $\hat{p}_{d}-\hat{p}_{f}-\hat{e}=0$. From (7), the balance-of- 
payments constrained equilibrium rate, $\hat{y}$, is then shown to be equal to the ratio between income elasticity of exports, $\beta$, and income elasticity of imports, $\varphi$, times the rest of the world's economic growth, $\hat{z}$ :

$$
\hat{y}=\frac{\beta}{\varphi} \hat{z}
$$

In its weak form ${ }^{1}$, Thirlwall's Law can be written as:

$$
\hat{y}=\frac{1}{\varphi} \hat{x}
$$

where $\hat{x}$ denotes the accomplished export rate growth, making it more inclusive of balance of payments complexities. One of the assumptions behind the derivation of Thirlwall's law (1979) is that all commercial partners are taken as a single entity, generally labelled as "the rest of the world". However, a country may have several commercial partners, which suggests a need to account for this through a more inclusive model. In this vein, Nell (2003) presented just such a derivation ${ }^{2}$, which allows us to understand how balance-of-payment constrained growth is affected by trade in a country with many commercial partners.

Although Nell's extension only takes two commercial partners into account, following Thirlwall (2013), we present a more general extension, which considers an arbitrary number of countries. As in Thirlwall (1979), Nell (2003) started from an intertemporal balance of payments equilibrium, represented by equation (6). The main modification introduced by Nell refers to export and import functions, which must now consider the existence of multiple commercial partners. Thus, in terms of growth rates, the export and import functions can be written as follows:

$$
\begin{aligned}
& \hat{x}=\eta\left(\hat{p}_{d}-\hat{p}_{f}-\hat{e}\right)+\sum_{j=1}^{m} \varepsilon_{j} w_{x j} \sigma_{y j} \\
& \hat{m}=\psi\left(\hat{p}_{f}+\hat{e}-\hat{p}_{d}\right)+\sum_{j=1}^{m} \pi_{j} w_{m j} \sigma_{y}
\end{aligned}
$$

where $\sigma_{y j}$ is the economic growth rate of the $j$-th commercial partner, $\sigma_{y}$ is the domestic economic growth rate, $w_{x j}$ is the relative participation of the $j$-th country in that country's exports and $\varepsilon_{j}$ is the income elasticity of exports to $j$-th country. Analogously, $w_{m j}$ is the relative participation of the $j$-th country in the country's imports and $\pi_{j}$ is the income elasticity of imports that the country has with each one of its commercial partners. By replacing equation (6) with equations (9) and

\footnotetext{
${ }^{1}$ Expression (8) can be obtained based on purchasing power parity (PPP) or the Marshall-Lerner condition. The equation (8)' derivation necessarily requires PPP. For this reason (8) is known as the strong version and (8)' the weak version of Thirlwall's Law.

${ }^{2}$ As McCombie (2012) points out, the idea of several commercial partners has been presented in some econometric studies, but the Multilateral Thirlwall's Law derivation, even when restricted to three countries, comes from Nell (2003).
} 
(10), following algebraic manipulation, Nell (2003) obtained the following equation, which is a generalization of Thirlwall's Law:

$$
\sigma_{y}=\frac{(1+\eta+\psi)\left(\hat{p}_{d}-\hat{p}_{f}-\hat{e}\right)+\sum_{j=1}^{m} \varepsilon_{j} w_{x j} \sigma_{y j}}{\sum_{j=1}^{m} \pi_{j} w_{m j}}
$$

Note that if we assume the PPP holds over the long-term, that is, $\hat{p}_{d}-\hat{p}_{f}-\hat{e}=0$, equation (11) turns into:

$$
\sigma_{y}=\frac{\sum_{j=1}^{m} \varepsilon_{j} w_{x j} \sigma_{y j}}{\sum_{j=1}^{m} \pi_{j} w_{m j}}
$$

In the same spirit of sectoral disaggregation, expression (11)' shows that a country can improve its growth performance by increasing the relative participation of specific commercial partners.

Nell, in his paper (2003), empirically tested his model by considering three commercial partners, namely: OECD, South Africa (SA) and the other countries in the Southern Africa Development Community (SADC). The results were largely favourable in confirming the Multilateral Thirlwall Law, with predicted growth rates in SA and the SADC almost coinciding with the actual rates. The econometric analysis demonstrated that SA's main growth restriction concerns trade with the OECD, which requires a policy to increase the income elasticity of the export of SA products to increase its share of trade with OECD countries. Meanwhile, the most significant restriction faced by the SADC countries occurred in relation to SA, meaning that these countries may grow more quickly by increasing their trade with OECD countries. For this to happen, however, it is also necessary to increase the added value of the goods produced and exported by the SADC countries.

\section{THIRLWALL'S LAW AND THE MULTISECTOR EXTENSION}

Excluding the effects of the exchange rate on the balance of payments, while emphasizing structural change, Araujo and Lima (2007) derived a multisector version of the balance-of-payments constrained hypothesis. In their version, the economic growth rate not only depends on the income elasticity ratio, but also on each sector's share of exports. This analysis highlighted an important fact that had not been considered by other authors: structural changes play an important role in long-term economic performance [see McMillan and Rodrik (2011), Ocampo (2005), Ocampo, Rada and Taylor (2009) and Thirlwall (2013)].

To derive the Multisector Thirlwall's Law, we used a pure labour version of the Passinetian model. On the one hand, it is reasonable to assume that if $p_{i}^{U} \geq e p_{i}^{A}$, 
where $p_{i}^{U}$ and $p_{i}^{A}$ are the prices of $i$-th good in countries $U$ and $A$, then country $U$ does not have a comparative advantage in the production of good $i$ and, therefore, the export demand for good $i$ is equal to zero, that is, $x_{i n}^{U}=0$. On the other hand, if $p_{i}^{U}<e p_{i}^{A}$, then the export demand for good $i$ is given by a Cobb-Douglas equation:

$$
x_{i \hat{n}}^{U}=\left(\frac{p_{i}^{U}}{e p_{i}^{A}}\right)^{\eta_{i}} Y_{A}^{\beta_{i}}
$$

where $x_{i n}^{U}$ is the foreign demand for good $i, \eta_{i}$ is the elasticity price of the export of good $i$-th, with $\eta_{i}<0$, while $\beta_{i}$ is the income elasticity of exports for the good and $Y_{A}$ is the national income of country $A$. By dividing both sides of equation (12) by country $A$ 's population, given as $X_{\hat{n}}$, we obtain the foreign per capita demand coefficient of good $i$ :

$$
a_{i \hat{n}}^{U}=\left\{\begin{array}{cl}
\left(\frac{p_{i}^{U}}{e p_{i}^{A}}\right)^{\eta_{i}} Y_{A}^{\beta_{i}} X_{\hat{n}}^{1-\beta_{i}} & \text { if } p_{i}^{U}<e p_{i}^{A} \\
0 & \text { if } p_{i}^{U} \geq e p_{i}^{A}
\end{array}\right.
$$

where $y_{A}$ is the foreign per capita demand of country $A$.

Analogously, if country $A$ does not have comparative advantage in the production of $\operatorname{good} i$, then the per capita import demand of country $U$ for good $i$ is equal to zero, that is, $x_{\hat{i n}}=0$. But if $p_{i}^{U} \geq e p_{i}^{A}$ then we consider that import demand is given a standard demand function, as follows:

$$
x_{\text {in }}^{U}=\left(\frac{e p_{i}^{A}}{p_{i}^{U}}\right)^{\psi_{i}} Y_{U}^{\phi_{i}}
$$

where $\Psi_{i}$ is the price elasticity of import demand for good $i$, with $\Psi_{i}<0$, and $\phi_{i}$ is the income elasticity of import demand for good $i$, while $Y_{U}$ is the domestic income of $U$. By dividing both sides of equation (14) by country $U$ 's population, we obtain the per capita domestic coefficient of the import demand for good $i$ :

$$
a_{\hat{i n}}^{U}=\left\{\begin{array}{cl}
\left(\frac{e p_{i}^{A}}{p_{i}^{U}}\right)^{\psi_{i}} Y_{U}^{\phi_{i}} X_{n}^{1-\phi_{i}} & \text { if } p_{i}^{U}>e p_{i}^{A} \\
0 & \text { if } p_{i}^{U} \leq e p_{i}^{A}
\end{array}\right.
$$

When $p_{i}^{U}<e p_{i}^{A}$, we take the natural logarithm on both sides of expression (13) and differentiate it with respect to time. The following convention is adopted: 
$\frac{p_{i}}{p_{i}}=\sigma_{i}^{U}, \frac{p_{\hat{i}}}{p_{\hat{~}}}=\sigma_{i}^{A}, \frac{\dot{e}}{e}=\varepsilon, \frac{y_{A}}{y}=\sigma_{y}^{A}, \frac{X_{\hat{n}}}{X_{\hat{n}}}=\hat{g}$. Hence the growth rate of external demand per capita of good $i$-th is given by:

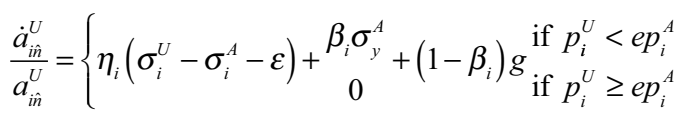

Adopting the same procedure with respect to expression (15), where $p_{i}^{U} \geq e p_{i}^{A}$, and adopting notation $\frac{y_{U}}{y_{U}}=\sigma_{y}^{U}$ and $\frac{X_{n}}{X_{n}}$, the following growth rate is obtained for the domestic coefficient of per capita demand for the $i$-th good:

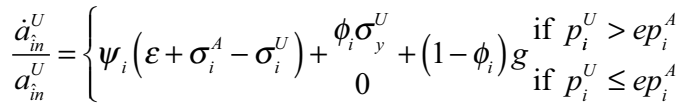

Let us assume that both populations remain constant over time and that $\sigma_{i}^{U}-\sigma_{i}^{A}-\varepsilon=0, \forall i=1, \ldots, n-1$, which means that the relative prices of the $i$-th good remain constant over time. In Thirlwall's aggregate model (1979), this hypothesis is based on the fact that, although the terms of trade may fluctuate over the short term, they will remain relatively stable over the long run - the PPP hypothesis. In this disaggregated version, the explanation is that we are only considering tradable goods with no trade barriers and no transportation costs. In this way, the law of one price can be invoked to ensure that in the long term $\sigma_{i}^{U}-\sigma_{i}^{A}-\varepsilon=0, \forall i=1, \ldots, n-1$. In this case, expressions (16) and (17) can be written respectively as:

$$
\begin{aligned}
& \frac{\dot{a}_{i \hat{n}}^{U}}{a_{i \hat{n}}^{U}}=\beta_{i} \sigma_{y}^{A} \\
& \frac{\dot{a}_{\hat{i} n}^{U}}{a_{\hat{i n}}^{U}}=\phi_{i} \sigma_{y}^{U}
\end{aligned}
$$

According to Araujo and Teixeira (2004), the dynamic equilibrium in the balance of payments is given by the following expression:

$$
\sum_{i=1}^{n-1}\left(\xi a_{i \hat{n}}-a_{\hat{i n}}\right) a_{n i}+\sum_{i=1}^{n-1}\left(\xi a_{i \hat{n}}-a_{\hat{i} n}\right) a_{n i}=0
$$

We consider the case where there is no technological progress to be $a_{n i}(t)=0$. In this case, expression (18) is reduced to:

$$
\sum_{i=1}^{n-1}\left(\xi a_{i \hat{n}}-a_{\hat{i n}}\right) a_{n i}=0
$$


Substituting equations (16)' and (17)' with equation (18)', following algebraic manipulation, the following expression, which embodies the Multisector Thirlwall's Law (MSTL), is obtained:

$$
\sigma_{y}^{U}=\frac{\sum_{i=1}^{n-1} \xi \beta_{i} a_{i \hat{n}} a_{n i}}{\sum_{i=1}^{n-1} \phi_{i} a_{\hat{i n}} a_{n i}} \sigma_{y}^{A}
$$

Expression (19) shows that the sectoral composition of an economy may affect its growth rate, since the composition reflects each sector's participation in the export and import trade. The result highlights the fact that the ratio of income elasticity (exports / imports) in the aggregate version (Thirlwall's Law) can be translated in the disaggregated version (LTMS) as the numerator of the weighted sum of the income elasticity of the $n-1^{3}$ sectors which constitute the country's exports. If we examine the denominator, we also find the sum of the $n-1$ sectors, which constitute the country's import structure. As these compositions change over time, they explain fluctuations in the income elasticity ratio (exports / imports) and thus explain the sensitivity of domestic growth to growth in the rest of the world.

Araujo and Lima (2007), have used this approach to demonstrate that the benefits of international trade for economic growth depend, to a large extent, on the ratio of the income elasticity of exports and imports in sector terms, that is, the higher the income elasticity of demand for the export sector and the lower the income elasticity of demand for the import sector, the greater the benefits of this bilateral relationship with the rest of the world. In sum, their result is like that presented by Thirlwall (1979), but took into consideration the coefficient-weighted income elasticity that measures each sector's participation in total imports and exports. The empirical literature regarding this multisector approach has gained ground in recent years, since several works address it. These include: Gouvêa and Lima (2010), Carbinato (2010), Queiroz, Spolador, Higachi and Castilho (2011), Soares (2012), Soares and Teixeira (2012) and Santos (2014).

\section{THE MULTILATERAL AND MULTISECTOR THIRLWALL'S LAW}

We constructed our model based on the above formulations from Araujo and Lima (2007) and Nell (2003). One of the basic assumptions of the multisector model is the equilibrium condition in the trade balance, which will be reproduced once again, although now it is disaggregated by trading partners:

$$
\sum_{i=1}^{n-1} \sum_{j=1}^{m}\left(\xi_{j} a_{\hat{i}}-a_{\hat{i}}\right) a_{n i}=0
$$

\footnotetext{
${ }^{3}$ In its multisector model, Pasinetti (1981) considers the $n$-th sector to be the family sector (labour force).
} 
where the term $a_{\hat{i j}}$ represents the demand for per capita exports from the $i$-th sector to the $j$-th trade partner, or simply the external demand coefficient, and the term $a_{\hat{i} j}$ symbolizes the demand for domestic per capita imports from the $i$-th sector provided by partner $j$, or simply, the domestic demand coefficient. The coefficients of production of $n-1$ consumer goods are given as $a_{n i}$. The size of the countries' populations is bilaterally related by a coefficient of proportionality, $\xi_{j}=X_{j} / X$, for each commercial partner $j$.

The domestic demand function for exports to commercial partners has the following functional form:

$$
x_{i j}=\left(\frac{p_{i}}{p_{i j} e_{j}}\right)^{\eta_{i j}} Y_{j}^{\beta_{i j}}
$$

where $x_{\hat{i}}$ represents the demand coefficient of country $j$ for domestically produced good $i, p_{i}$ represents the domestic price of $i$-th commodity, $p_{i j}$ is the price of the $i$-th commodity implemented by the trading partner $j, e_{j}$ represents the bilateral nominal exchange rate between the country under consideration and the $j$-th trading partner, $\eta_{i j}$ is the price elasticity of demand for good $i$, with $\eta_{i j}<0$, while $\beta_{i j}$ is the income elasticity of demand for exports and $Y_{j}$ is the income of trading partner $j$. By dividing both sides of equation (21) by the population of country $j$, given by $X_{j}$, we arrive at the coefficient of the per capita external demand for domestic good $i$ :

$$
a_{i j}=\left(\frac{p_{i}}{p_{i j} e_{j}}\right)^{\eta_{i j}} Y_{j}^{\beta_{i j}} X_{j}^{\beta_{i j}-1}
$$

where $y_{j}$ represents the per capita income of trading partner $j$.

In addition, if the trading partner does not have a comparative advantage in producing good $i$, the per capita domestic import of good $i$ will be zero. However, if $p_{i}>p_{i j} e_{j}$, then it is necessary to consider the import demand coefficients given by a standard domestic import demand function, which has the following functional form:

$$
x_{i j}=\left(\frac{p_{i}}{p_{i j} e_{j}}\right)^{-\psi_{i j}} Y^{\phi_{j j}}
$$

where $\psi_{i j}$ is the price elasticity of demand for imports of good $i$ from partner $j$, with $\psi_{i j}<0$ and $\varphi_{i j}$ is the income elasticity of the domestic demand of sector $i$ for imports from partner $j$ and $Y$ is real domestic income. Dividing both sides of (23) by the domestic population, given as $X$, we reach the coefficient of per capita import of good $i$ :

$$
a_{\hat{i j}}=\left(\frac{p_{i}}{p_{i j} e_{j}}\right)^{-\psi_{i j}} y^{\phi_{i j}} X^{\phi_{i j}-1}
$$


where $y$ is the domestic per capita income.

One can apply the natural logarithm on both sides of (22) and (24) and differentiate with respect to time. Moreover, we can define the following terms to simplify the notation: $\frac{p_{i}}{p_{i}}=\sigma_{i}, \frac{p_{i j}}{p_{i j}}=\sigma_{i j}, \frac{e_{j}}{e_{j}}=\varepsilon_{j}, \frac{y}{y}=\sigma_{y}, \frac{y_{j}}{y_{j}}=\sigma_{y,}, \frac{X_{j}}{X_{j}}=g_{j}$ and $\frac{X}{X}=g$. We now consider the following growth rate of the external demand coefficient for good $i$ for each of the $m$ partners:

$$
a_{i \hat{j}}=a_{i j} \eta_{i j}\left(\sigma_{i}-\sigma_{i j}-\varepsilon_{j}\right)+a_{i j} \beta_{i j} \sigma_{y j}+a_{i \hat{j}}\left(\beta_{i j}-1\right) g_{j}
$$

Taking the same procedure for equation (24), we have:

$$
a_{\hat{i}}=-a_{i \hat{j}} \psi_{i j}\left(\sigma_{i}-\sigma_{i j}-\varepsilon_{j}\right)+a_{\hat{i j}} \varphi_{i j} \sigma_{y}+a_{i \hat{j}}\left(\varphi_{i j}-1\right) g
$$

Consider, for the sake of simplicity, that the countries' populations do not grow and that the dynamic version of the law of the single price for all countries and sectors $\sigma_{i}-\sigma_{i j}-\varepsilon_{j}=0, \forall i=1, \ldots, n-1$ and $\forall j=1, \ldots, m$, then the equation of the growth rate of the external demand coefficient can be rewritten as follows:

$$
a_{\hat{i j}}=a_{\hat{i j}} \beta_{i j} \sigma_{y j}
$$

Adopting the same assumptions in relation to the domestic demand coefficient growth rate, we obtain the following expression:

$$
a_{\hat{i j}}=a_{\hat{i j}} \varphi_{i j} \sigma_{y}
$$

For the trade balance equilibrium condition to remain valid over time, the following condition must be satisfied:

$$
\sum_{i=1}^{n-1} \sum_{j=1}^{m}\left(\xi_{j} a_{i j}-a_{i j}\right) a_{n i}+\sum_{i=1}^{n-1} \sum_{j=1}^{m}\left(\xi_{j} a_{i j}-a_{i j}\right) a_{n i}=0
$$

Assuming that there is no technical progress in any sector, that is, $a_{n i}=0$ for all $i$ and replacing equations (27) and (28) with (29), we finally arrive at the multisector and multilateral version of Thirlwall's law, which is represented in the following way:

$$
\sigma_{y}=\sum_{j=1}^{m}\left(\frac{\sum_{i=1}^{n-1} \xi_{j} a_{n i} a_{\hat{i j}} \beta_{i j}}{\sum_{i=1}^{n-1} a_{n i} a_{\hat{j} j} \varphi_{i j}}\right) \sigma_{y j}
$$

where the rate of domestic per capita economic growth, $\sigma_{y}$, depends on each good's share of exports to each trading partner, $a_{n i} a_{\hat{i} j}$, on the income elasticity of exports for each product of each partner, $\beta_{i j}$, on the income elasticity of imports for each product of each partner, $\varphi_{i j}$, on each good's share of the imports of each trad- 
ing partner, $a_{n i} a_{\hat{i} i}$, and, finally, on the economic growth rates of trading partners weighted by the population ratio $\xi_{j} \sigma_{j}$.

We note that the derivation of the MSTL from a multilateral perspective adds a new element to the balance-of-payments constrained growth rate of the economy. The coefficient of proportionality between the country's population and its trading partners, $\xi_{j}$, now plays an important role in determining domestic economic growth rate. Each trading partner's population is relevant insofar as it may reinforce the transmission of each partner's economic growth to growth in the domestic economy. The $\xi_{j}$ position in the equation reveals that partner countries with a population significantly larger than the domestic population tend to contribute the most to the economic growth rate. This means that, given two trading partners growing at the same rate, the one with the larger population will make a greater contribution to domestic economic growth. This result is reasonable, since it is expected that a larger population has a higher aggregate demand and, consequently, higher imports, which may be converted into higher exports and greater economic growth. In addition, this allows us to understand the relationship between sectors, commercial partners and domestic economic growth. From this equation, one can determine the relative weight of each sector and commercial partner in the composition of the economic growth rate. This parameter must therefore be considered when outlining a trade strategy.

Another issue to consider is the simultaneous determination of the growth rate of the countries involved in international trade in this multilateral version. If the growth rate of the country in question is determined by the growth rate of the other countries, these will, in turn, be influenced by its growth rate. This further highlights the interdependence of economies involved in international trade, since an increase in a country's growth rate will lead to an increase in the rate of growth of the product and, consequently, the growth rate of imports, leading to an increase in the growth rate of some of its trading partners, through increased exports. Another resource that enables a better understanding of expression (18) is the use of the following quotient:

$$
\Delta_{j ;}=\frac{\sum_{i=1}^{n-1} a_{n i} a_{i j} \beta_{i j}}{\sum_{i=1}^{n-1} a_{n i} a_{i j} \varphi_{i j}}
$$

Replacing (31) with (30), we have the following expression:

$$
\sigma_{y}=\sum_{j=1}^{m} \Delta_{j} \xi_{j} \sigma_{y j}
$$

From equation (32), if the ratio between the sum of the income elasticity of exports and the sum of the income elasticity of imports, weighted by their respective trade patterns, is greater than one unit, $\Delta_{j}>1$, then the economic growth of 
the $j$-th commercial partner, namely $\sigma_{y j}$, will drive domestic growth at a more than proportional rate. On the other hand, if $\Delta_{j} \in(0,1)$, then domestic growth will be less than the proportional growth of country $j$. Moreover, by establishing two trading partners $j_{1}, j_{2}, \in\{1, \ldots m\}$, with the same population, economically growing at the same rate and with $\Delta_{i_{1}}>\Delta_{i_{2}}$, then trade partner $j_{1}$ contributes more to domestic growth than $j_{2}$.

In this way, it is possible to measure the effects of each trading partner's sector growth on domestic economic growth. This approach allows us to determine which sector-partner pairs contribute most to economic growth in the domestic economy. From this, we can define the country's best international insertion strategy, valuing and strengthening the most important trade relations for domestic growth, and re-evaluating and proposing renegotiations for those that contribute the least to national development.

A proposal for a public international trade policy which aims to improve the domestic trade tariff with a specific partner, increasing the composition of products with high income elasticity of demand for exports, is one example of an economic policy that favours domestic growth.

Another public policy that aims to impose barriers on the import of products with high income elasticity of demand for imports, reducing these imported products' share of the import tariff, is one example of an economic policy that also favours national economic growth. Policy makers can therefore propose economic policies that will improve both trade relations and the Brazilian economy's competitiveness, adjust the long-term economic growth rate and drive the economy to a higher developmental stage.

\section{NUMERICAL SIMULATIONS}

This section aims to discuss, in numerical terms, the evolution of a fictitious country's per capita GDP, one with features similar to the Brazilian economy in terms of trade relations with fictitious trade partners, in two different economic scenarios. To this end, we performed certain numerical simulations to understand the pattern of commerce of this fictitious Brazilian economy, focusing on the countries registered by COMTRADE $(2014)^{4}$ as Brazil's main trade partners, that is, China, the United States and Argentina.

From this perspective, we considered two scenarios, the current situation, in

\footnotetext{
${ }^{4}$ According to COMTRADE, in 2014, the USA was Brazil's second biggest export market, with $12.1 \%$ of Brazilian exports and $15.4 \%$ of its imports. Most of this commerce was in mineral fuels, oil and distillation goods. China is Brazil's biggest international trade market. Exports to China total $18 \%$, while imports are at $16.3 \%$. The goods most transacted are oleaginous seeds, grains, seeds, fruits and electronic equipment. Argentina is also one of Brazil's great trading partners. In 2014, Brazilian exports to Argentina were $6.3 \%$ of the total, while imports were $6.2 \%$. The goods most frequently traded are vehicles other than trains, nuclear, plastic reactor and railroad items.
} 
which the simulated Brazilian economy has a structure similar to the Brazilian economy (concentrated on primary goods) and an alternative scenario in which structural change takes place and the economy begins to display features similar to a Kaldorian structure (with industry as the main sector).

In the construction of the MATLAB language script, we obtained the export and import income elasticity and the per capita economic growth of the fictitious countries from Paiva $(2015)^{5}$. The intention was to reproduce numerically what is presented analytically in equation (18), except for the coefficient of population ratio, $\xi_{i}$, in which we assumed unity for all trade partners, $\xi_{j}=1$, for the sake of simplicity.

We used a new equation for the construction of the trade partners' growth rates, since these taxes are exogenous in the proposed model. In this sense, we chose a simple equation to simulate economic growth in these countries, that is:

$$
\sigma_{y j}=\mu+\delta e_{t}
$$

where $\mu$ represents the observed average of the economic growth in country $j$, $\delta$ is the standard deviation, and $e_{t}$ is white noise with zero average and a standard deviation of one $^{6}$. In constructing this script, once in possession of growth rates and income elasticity, it was possible to infer, endogenously, the simulated Brazilian economy's growth performance for the next 50 years.

\section{Current Scenario without Structural Change}

\section{(i) Parameters and Initial Conditions}

The initial condition references for the countries' per capita GDP were based on the real 2013 value, normalizing the Chinese per capita GDP. In 2013, the per capita GDP of Brazil, China, Argentina and the United States was U\$ 11,208.08; U\$ 6,807.43; U\$ $14,715.18$ and U\$ 53,041.98 respectively. Thus, without losing generality, the per capita GDP of China is considered equal to one, that of Brazil is equal to 1.8 , North America to 7.8 and Argentina to $2^{7}$.

Table 1 presents the income elasticity ratio of exports and imports for the fictitious economy with features similar to the Brazilian economy. The adopted

\footnotetext{
${ }^{5}$ Gabriel et al. (2016) used a dynamic equation to describe the share of industry in GDP, creating a process of structural change towards sectors with greater income elasticity of demand for exports. In this paper, structural change is exogenous - our intention is simply to compare two different scenarios, in one of which these are favorable, while in the other they are not favorable for the country in question.

${ }^{6}$ Notice that with simulated economic growth for a matching commercial situation, the fluctuation is above the observed average, providing an empirical component for the numerical simulation. In this sense, if the average rate of economic growth of any partner is, for example, $4 \%$ p.a. then it is expected that for each simulated year this rate will float within the interval $[0.03 ; 0.05]$, with a probability above $68 \%$.

${ }^{7}$ These results were obtained when too many countries divided the Chinese per capita GDP by the $y_{\text {China }}$ per capita GDP. This has therefore been calculated as $y^{\text {Brazil }} / y^{\text {China }} \cong 1.64 ; y^{\text {Argentina }} / y^{\text {China }} \cong 2.16 ; y^{\text {Brezil }} / y^{\text {China }} \cong$ 1.64 and $y^{U S A} / y^{\text {China }} \cong 7.80$.
} 
parameters for the income elasticity ratios between exports and imports for each trade partner in the current scenario were drawn from Paiva (2015). Notice that each value contained in Table 1 represents the ratio when a trade partner was fixed for any $j$ between the income elasticity of exports of the $i$-th sector, $\beta_{i j}$, taken as its participation in the export list, $a_{n i} a_{i j}$, and the income elasticity of the collected imports.

Table 1: Income Elasticity Ratio of Demand for Exports and Imports Used in the Numerical Simulation - Current Scenario

\begin{tabular}{|c|c|c|c|}
\hline $\begin{array}{l}\text { Partner/ } \\
\text { Sector }\end{array}$ & Industry (1) & Service (2) & Agriculture (3) \\
\hline China (A) & $\frac{a_{n 1} a_{1 \hat{A}} \beta_{1 A}}{\sum_{i=1}^{3} a_{n i} a_{\hat{t A}} \varphi_{i A}}=0.0114$ & $\frac{a_{n 2} a_{2 \hat{A}} \beta_{2 A}}{\sum_{i=1}^{3} a_{n i} a_{\hat{i A}} \varphi_{i A}}=0.0512$ & $\frac{a_{n 3} a_{3 \hat{A}} \beta_{3 A}}{\sum_{i=1}^{3} a_{n 1} a_{\hat{1} A} \varphi_{1 A}}=0.0966$ \\
\hline USA (B) & $\frac{a_{n 1} a_{1 \hat{B}} \beta_{1 B}}{\sum_{i=1}^{3} a_{n i} a_{\hat{i} B} \varphi_{i B}}=0.0105$ & $\frac{a_{n 2} a_{2 \hat{B}} \beta_{2 B}}{\sum_{i=1}^{3} a_{n i} a_{i B} \varphi_{i B}}=0.0146$ & $\frac{a_{n 3} a_{3 \hat{B}} \beta_{3 B}}{\sum_{i=1}^{3} a_{n i} a_{\hat{i B}} \varphi_{i B}}=0.0056$ \\
\hline Argentina $(\mathrm{C})$ & $\frac{a_{n 1} a_{1 \hat{C}} \beta_{1 C}}{\sum_{i=1}^{3} a_{n i} a_{\hat{i} C} \varphi_{i C}}=0.05 \square 0$ & $\frac{a_{n 2} a_{2 \hat{C}} \beta_{2 C}}{\sum_{i=1}^{3} a_{n i} a_{i C} \varphi_{i C}}=0.005 \square$ & $\frac{a_{n 3} a_{3 \hat{C}} \beta_{3 C}}{\sum_{i=1}^{3} a_{n i} a_{\hat{1} C} \varphi_{i C}}=0.005$ \\
\hline
\end{tabular}

Source: Author's own.

This scenario contemplates an economy with a structure different from the Kaldorian economic structure, since the share of goods with higher income elasticity (industry) in exports is lower than the share of primary goods and, for this reason, the ratio values for the income elasticity of exports and imports in the industrial sector are low.

\section{(ii) Random Variable Construction}

As previously stated, the trade partners' rates of economic growth were constructed on the basis of the average rates observed between 1979 and 2012. To achieve this, we added a random component independent of the series to the drift value, i.e., one not auto-correlated with the lagged values. The construction of each of these growth rates may be found in equation (21).

\section{(iii) Results}

Here we present the results of the computational simulations for the current scenario (without structural change). In Figure 1, we can see a comparison between the simulated rate of economic growth for Brazil, China, Argentina and the USA. Notice that the simulations preserve the initial features and patterns observed for these countries. The Chinese economy maintains a trend for fast growth, while the Brazilian economy loses pace over time. The reason for this is that in such a scenario the Brazilian economy does not present a Kaldorian structure, in other words, 
the relative principal component of GDP is the primary, rather than the industrial, sector, which produces goods with low income elasticity of demand.

Thus, although the export-primary sector contributes to balance of trade surpluses, it is not a dynamic sector in the Kaldorian sense, that is, not one which can help the country catch up with the most developed economies.

Figure 1: Simulated per capita GDP Growth Rate for Selected Countries

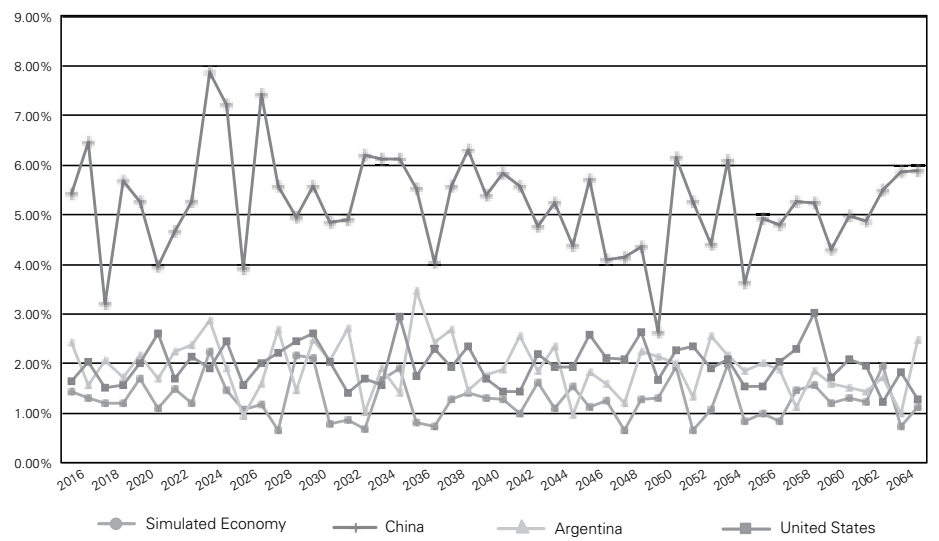

Growth rate of per capita GDP. Source: Author's own.

Figure 2 presents the evolution of (normalized) per capita GDP for Brazil, Argentina, United States and China. For the simulation, ceteris paribus, in a few years, Brazil's per capita GDP will be lower than Argentina's and China's, due to the exhaustion of the primary goods export model. We note that the per capita GDP of the Chinese economy is moving away from emerging economies and approaching the per capita GDP observed in developed countries, such as the USA.

Figure 2: Simulation of the Evolution of the Selected Countries' per capita GDP

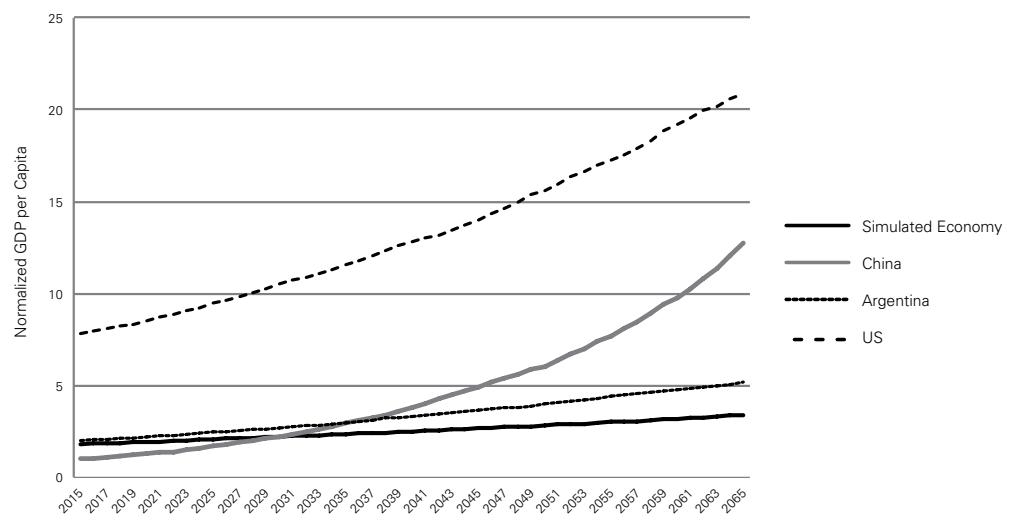

Normalized per capita GDP. Source: Author's own. 
Figure 3 shows the decomposition of the simulated GDP for the fictitious economy, in other words, the share of each sector and trade partner. Note that exports from the Chinese agriculture and services sectors contributed $19 \%$ to that country's total economic growth. Exports of industrial goods to trade partners were low, contributing less than $20 \%$.

Figure 3: GDP Share Simulation in the Fictitious Economy

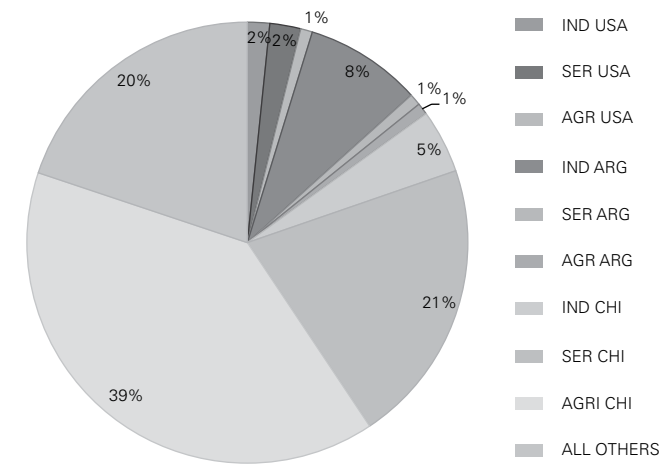

Average share over of GDP. Source: Author's own.

It is therefore possible to demonstrate that, in the absence of structural change towards a Kaldor structure, growth in the Brazilian economy remains low, obstructing catch-up (i.e., a reduction in the per capita GDP difference between a developed country and Brazil) in reasonable time.

\section{Structural Change Scenario}

(i) Parameters and Initial Conditions

Similar to the previous scenario, Table 2 was fed with arbitrary parameter values. We also maintained the countries' initial conditions. The new parameter table is therefore as follows:

Table 2: Income Elasticity Ratio of Demand for Exports and Imports Used in the Numerical Simulation - Structural Change Scenario

\begin{tabular}{|c|c|c|c|}
\hline $\begin{array}{l}\text { Partner/ } \\
\text { Sector }\end{array}$ & Industry (1) & Service (2) & Agriculture (3) \\
\hline China (A) & $\frac{a_{n 1} a_{1 \hat{A}} \beta_{1 A}}{\sum_{i=1}^{3} a_{n i} a_{\hat{i} A} \varphi_{i A}}=0.4566$ & $\frac{a_{n 2} a_{2 \hat{A}} \beta_{2 A}}{\sum_{i=1}^{3} a_{n i} a_{\hat{i A}} \varphi_{i A}}=0.0512$ & $\frac{a_{n 3} a_{3 \hat{A}} \beta_{3 A}}{\sum_{i=1}^{3} a_{n 1} a_{\hat{1} A} \varphi_{1 A}}=0.0914$ \\
\hline USA (B) & $\frac{a_{n 1} a_{1 \hat{B}} \beta_{1 B}}{\sum_{i=1}^{3} a_{n i} a_{\hat{i} B} \varphi_{i B}}=0.2005$ & $\frac{a_{n 2} a_{2 \hat{B}} \beta_{2 B}}{\sum_{i=1}^{3} a_{n i} a_{\hat{i} B} \varphi_{i B}}=0.0146$ & $\frac{a_{n 3} a_{3 \hat{B}} \beta_{3 B}}{\sum_{i=1}^{3} a_{n i} a_{i B} \varphi_{i B}}=0.0056$ \\
\hline Argentina (C) & $\frac{a_{n 1} a_{1 \hat{C}} \beta_{1 C}}{\sum_{i=1}^{3} a_{n i} a_{i C} \varphi_{i C}}=0.35 \square 0$ & $\frac{a_{n 2} a_{2 \hat{C}} \beta_{2 C}}{\sum_{i=1}^{3} a_{n i} a_{\hat{i} C} \varphi_{i C}}=0.005 \square$ & $\frac{a_{n 3} a_{3 \hat{C}} \beta_{3 C}}{\sum_{i=1}^{3} a_{n i} a_{\hat{1} C} \varphi_{i C}}=0.005$ \\
\hline
\end{tabular}

Source: Author's own. 
Nevertheless, in this scenario, the share of the export of goods with higher elasticity of demand (industry) is relatively larger than in the current scenario.

(ii) Construction of Random Variables

Once again, we maintained the same rule as the previous scenario for the construction of the random variables.

(iii)Results

Here, we present the results of the computational simulations for the new scenario, i.e., that with structural change towards a Kaldorian structure (with industry having a higher share of GDP).

In Figure 4, there is a parallel between the simulated economic growth for these economies: Brazil, the United States, Argentina and China. The simulation with structural change considers the fact that Chinese growth may considerably exceed the economic growth of Brazil. With a structural change towards the most dynamic sector of the economy, i.e., the industrial sector, the country exhibits a growth trajectory which is supported over time, since these industrial goods have high elasticity of demand.

Figure 4: Economic Growth Simulations for Selected Countries in the Context of Structural Change in the Fictitious Economy

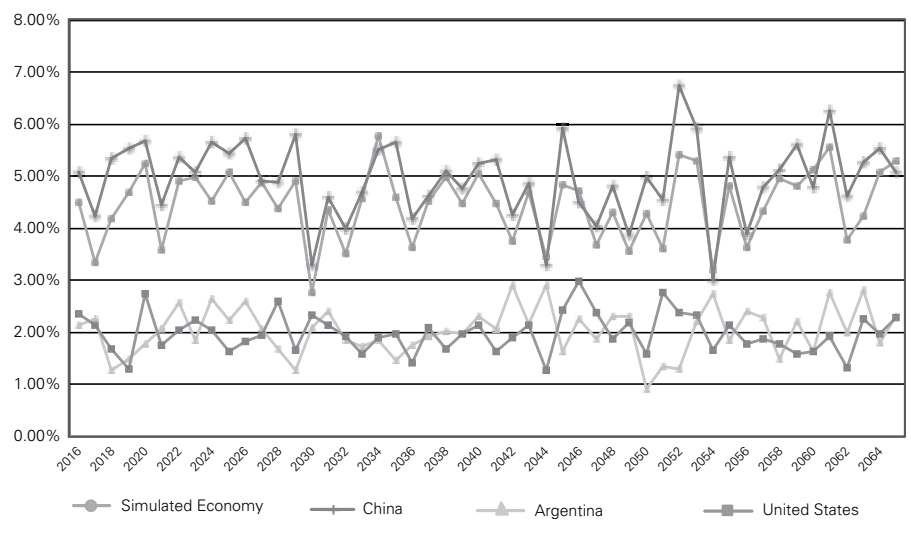

Growth rate of per capita GDP. Source: Author's own.

Figure 5 presents expansion in per capita GDP (normalized from 0 to 1 ) for the following economies: Brazil, Argentina, the United States and China. Unlike in the previous scenario, structural change produced more robust economic growth in the Brazilian economy, maintaining its level of per capita GDP above that of Argentina and China, although not enabling an increase of per capita output gap to catch up with the United States.

As a consequence of structural change, the Brazilian economy was able to catch up with Argentina's per capita GDP and maintain its level above Argentina and China. There was therefore a relative increase in the Brazilian's economy level of development, since the country approached the per capita GDP of the most developed countries. 
Figure 5: Simulation of the Evolution of the per capita GDP of Selected Countries in the Context of Structural Change in the Fictitious Economy

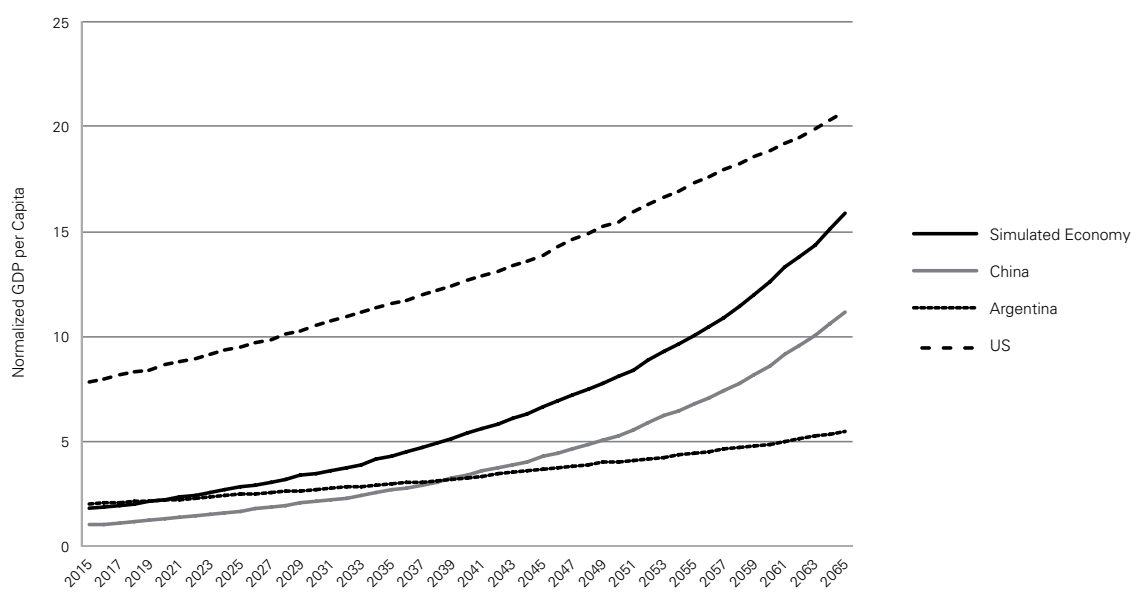

Normalized per capita GDP. Source: Author's own.

Figure 6 allows us to identify which sectors and trade partners contributed the most to Brazilian economic growth. Exports of industrialized goods to the United States, China and Argentina represent around $80 \%$ of Brazilian exports. The economic dynamic driven by exports from sectors with high income elasticity significantly stimulates domestic economic growth. Indeed, many sectors and countries contributed to the remaining $20 \%$, which we cannot overlook, but which reveals the supremacy of the industrial sector as one of the engines of economic growth.

Figure 6: Simulation of the GDP Share of the Fictitious

Economy in the Context of Structural Change
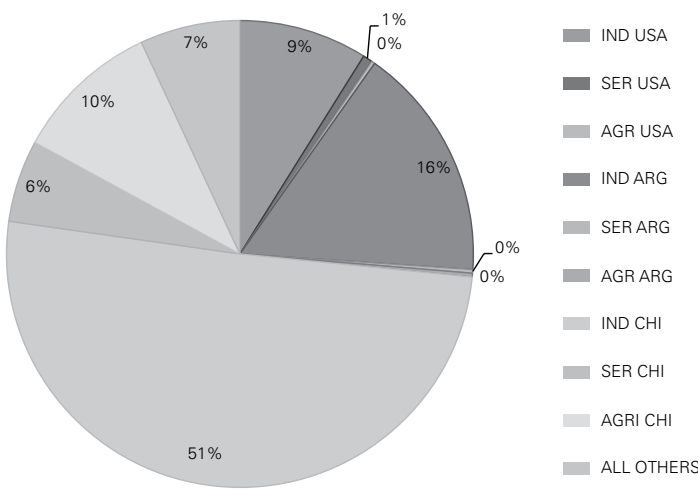

Average share over of GDP. Source: Author's own. 
In summary, this strategy is an alternative to allow developing countries to move towards the trajectory of sustainable economic growth over the coming years, since structural change enables growth recovery and improves the chance of catch-up.

These results agree with Ocampo and Parra's (2006) empirical findings, which support the negative and positive existence of correlation between economic growth, and the export of primary goods and structural change, respectively. Emerging economies which have not implemented structural change must look at exchange rate behaviour, since there is strong evidences that this is a key variable in this process [see, e.g., Bresser-Pereira (2008)]. If the country is successful in avoiding an appreciation of the real exchange rate, this will give rise to a virtuous growth cycle in which changes to external trade and the production structure are central to economic development.

\section{CONCLUSIONS}

This article had two main objectives, the first was the formal derivation of a disaggregated Thirlwall Law, in terms of both sectors and trading partners. The second, which was a consequence of the first, was to understand, through numeric simulations, the effect of the growth performance of certain trading partners on the growth rate of a developing economy similar to Brazil's.

From a theoretical point of view, we concluded that, from a multi-sector and multilateral perspective, the growth rate compatible with balance-of-payments equilibrium is not only affected by the income elasticity of exports and imports, but also by each sector's and trade partner's weight in terms of exports and imports. This result was also illustrated numerically, through the simulation of economic scenarios in fictitious economies.

These results indicate that structural change is strategic for the economic growth of developing countries, since it allows for greater dispersion of the positive effects of industrial productivity throughout the production chain, thereby increasing the value of trade terms when exporting products with greater added value. Moreover, when the country shifts towards the production of goods with higher income elasticity of demand it becomes less vulnerable to changes in the international situation. As observed in the simulations, a production structure based on the export of primary products does not allow developing economies, in particular Brazil, to catch up with developed economies. The importance of the export of industrial products to a trade partner with features similar to those of Argentina was therefore emphasized, once again highlighting the importance of consolidating trade with this partner as a significant channel to be explored by Brazil.

Finally, it would be interesting for a new research agenda to identify exactly which industrial subsectors and other partners may be strategic for domestic economic growth, expanding the debate about which sectors should be privileged by economic policies, that is, which industrial sectors can contribute most to bringing developing countries back onto the pathway to adequate economic growth. 


\section{REFERENCES}

ARAUJO, R. A. e TEIXEIRA, J. R. (2004) “A Pasinettian approach to international economic relations: the pure labor case”. Review of Political Economy, vol. 16(1), pages 117-129.

ARAUJO, R. A. e LIMA, G. T. (2007) "A Structural economics-dynamics approach to balance-of-payments constrained growth". Cambridge Journal of Economics, 755-774.

ARAUJO, R. e TRIGG, A. (2016) "A multi-sectorial assessment of the static Harrod foreign trade multiplier". European Journal of Economics and Economic Policies: Intervention. No prelo.

BARBOSA-FILHO, N. H. (2004) "Growth, exchange rates and trade in Brazil: a structuralist post Keynesian approach. Nova Economia, v. 14, n.2, p. 59-86.

BRESSER-PEREIRA, L.C. (2008) "Dutch disease and its neutralization: A Ricardian approach". Brazilian Journal of Political Economy 28(1): 47 - 71.

CARBINATO, D. A. (2010) "Crescimento econômico e estrutura produtiva no Brasil: uma análise das relações entre padrão setorial e restrição externa”. III Encontro da Associação Keynesiana Brasileira.

CASTILHO, M. L.; SPOLADOR, A. L.; Higachi, H. Y.; Queiroz, P. W. V. (2011) “Aplicabilidade da lei de Thirwall em setores selecionados da economia brasileira: uma análise do período 1962 a 2008. In: XIV Encontro de Economia da Região Sul - ANPEC SUL, Florianópolis. Anais do XIV Encontro de Economia da Região Sul - ANPEC SUL.

DUTT, A. K. (2002) “Thirlwall's law and uneven development”. Journal of Post Keynesian Economics, 24(3), 367-390.

ELLIOT, D. R. e RHODD, R. (1999) "Explaining growth rate differences in highly indebted countries: an extension to Thirlwall and Hussain". Applied Economics, 31.

GOUVÊA, R. R. e LIMA, G. T. (2010) "Structural change, balance-of-payments constraint, and economic growth: evidence from the multisectoral Thirlwall's law. Journal of Post Keynesian Economics, vol. 33(1), pages 169-204, October,

GABRIEL, L. F.; JAYME JUNIOR, F. G.; OREIRO, J.L. (2016) “A North-South model of economic growth, technological gap, structural change and real exchange rate". Structural Change and Economic Dynamics. Vol. 38, pages 83-94.

McMILLAN, M. S. and RODRIK, D. (2011) “Globalization, structural change and productivity growth. NBER Working Papers 17143, National Bureau of Economic Research, Inc.

McCOMBIE, J. S. L. and THIRLWALL, A. P. (1994) Economic Growth and The Balance-of-Payments Constraint. London: The Macmillan Press.

McCOMBIE, J. S. L. and THIRLWALL, A. P. (1997) "Economic growth and the balance of payments revisited.” In: ARESTIS, P., G. PALMA, M. SAWYER, M. (Eds.). Markets, Unemployment and Economic Policy: Essays in Honour of Geoffrey Harcout. London: Routledge, v. 2, p. 498-51.

MORENO-BRID, J. C. (1998) "Balance-of-payments constrains economic growth: The case of Mexico." Banca Nazionale del Lavoro Quarterly Review, p. 413-433.

NELL, K. S. A (2003) “'Generalised' version of the balance-of-payments growth model: An application to neighbouring regions." International Review of Applied Economics.

OCAMPO, J. (2005) "The quest for dynamic efficiency: structural dynamics and economic growth in developing countries”. In: J. Ocampo. Beyond Reforms: Structural Dynamics and Macroeconomic Vulnerability. Stanford University Press and The World Bank.

OCAMPO, J. A. ande M. A. PARRA, “The dual divergence: growth successes and collapses in the developing world since 1980”. DESA Working Paper No. 24.

OCAMPO, J. A., C. RADA, and L. TAYLOR (2009) Growth and Policy in Developing Countries: A Structuralist Approach. Columbia University Press.

PAIVA, M. S. (2015) Causação Cumulativa, Taxa de Câmbio Real e Progresso Tecnológico Endógeno em uma Abordagem Dinâmica de Mudança Estrutural Multilateral: Uma Análise Teórica e Empírica. Dissertação de Mestrado - Universidade Federal de Uberlândia.

PALLEY, T. (2002) "Pitfalls in the Theory of Growth: an application to the Balance-of-Payments Cons- 
trained Growth Model”, in M. Setterfield (ed) The Economics of Demand-led Growth. Edward Elgar, Cheltenham. pp 115-25.

SANTOS, H. S. (2014) A Lei de Thirlwall Multissetorial: Uma Análise das Elasticidades Renda das Exportações e Importações na Relação Bilateral Brasil China. Dissertação de Mestrado - Universidade Federal de Uberlândia.

SOARES, C. (2012) O Modelo de Balanço de Pagamentos Restrito e Desindustrialização: Teoria e Evidência Para o Caso Brasileiro. Tese (doutorado) - Universidade de Brasília.

SOARES, C. And J. R, TEIXEIRA (201) "A Lei de Thirlwall multissetorial: novas evidências para o caso brasileiro". ANPEC.

THIRLWALL, A. P. (1979) "The balance of payments constraint as an explanation of international growth rates differences". Banca Nazionale del Lavoro Quarterly, p. 44- 55.

THIRLWALL, A. P. and M. N. HUSSAIN (1982) "The balance of payments constraint, capital flows and growth rate differences between developing countries". Oxford Economic Papers: New Series.

THIRLWALL, A. P. (2013) Economic Growth in an Open Developing Economy: The Role of Structure and Demand. Edward Elgar, Cheltenham, UK and Northampton, MA, USA. 